\title{
DESMOID TUMOR IN PATIENTS WITH FAMILIAL ADENOMATOUS POLYPOSIS
}

\author{
Raquel Franco LEAL'1, Patricia V. V. Tapia SILVA'1, \\ Maria de Lourdes Setsuko AYRIZON01', João José FAGUNDES', \\ Eliane M. Ingrid AMSTALDEN² and Cláudio Saddy Rodrigues COY ${ }^{1}$
}

\begin{abstract}
Context - Desmoid tumors constitute one of the most important extraintestinal manifestations of familial adenomatous polyposis. The development of desmoids is responsible for increasing morbidity and mortality rates in cases of familial adenomatous polyposis. Objectives - To evaluate the occurrence of desmoid tumors in familial adenomatous polyposis cases following prophylactic colectomy and to present patient outcome. Methods - Between 1984 and 2008, 68 patients underwent colectomy for familial adenomatous polyposis at the School of Medical Sciences Teaching Hospital, University of Campinas, SP, Brazil. Desmoid tumors were found in nine $(13.2 \%)$ of these patients, who were studied retrospectively by consulting their medical charts with respect to clinical and surgical data. Results - Of nine patients, seven (77.8\%) were submitted to laparotomy for tumor resection. Median age at the time of surgery was 33.9 years (range 22-51 years). Desmoid tumors were found in the abdominal wall in 3/9 cases (33.3\%) and in an intra-abdominal site in the remaining six cases $(66.7 \%)$. Median time elapsed between ileal pouch-anal anastomosis and diagnosis of desmoid tumor was 37.5 months (range 14-60 months), while the median time between colectomy with ileorectal anastomosis and diagnosis was 63.7 months (range 25-116 months). In 6/9 (66.7\%) patients with desmoid tumors, the disease was either under control or there was no evidence of tumor recurrence at a follow-up visit made a mean of 63.1 months later (range 12-240 months). Conclusions - Desmoid tumors were found in $13.2 \%$ of cases of familial adenomatous polyposis following colectomy; therefore, familial adenomatous polyposis patients should be followed-up and surveillance should include abdominal examination to detect signs and symptoms. Treatment options include surgery and clinical management with antiestrogens, antiinflammatory drugs or chemotherapy. HEADINGS - Fibromatosis, abdominal. Adenomatous polyposis coli. Anastomosis, surgical. Colonic pouches.
\end{abstract}

\section{INTRODUCTION}

Desmoid tumors are mesenchymal neoplasms resulting from the proliferation of well-differentiated fibroblasts. They are benign, non-metastasizing fibrous masses; however, they are locally aggressive. Desmoids may occur sporadically or in association with familial adenomatous polyposis (FAP) and may be extraabdominal, intra-abdominal or located in the abdominal wall ${ }^{(21,27)}$. The etiology of these tumors is not completely clear, but in FAP patients, their development has been associated with mutations occurring beyond codon 1444 of the adenomatous polyposis coli (APC) gene $^{(2,16)}$. In addition, other factors that have been identified as predictors of desmoids in FAP cases include being female, previous abdominal surgery, pregnancy, exposure to oral contraceptives, a family history of desmoids and the presence of osteomas ${ }^{(2,8,12)}$.

Although rare in the general population, with an annual incidence of just 2-4 cases per million inhabitants, desmoid tumors are a common extracolonic manifestation of FAP, with a prevalence of $10 \%$ -
$20 \%$ in these patients ${ }^{(3,8,30)}$. Patients with FAP have a 1000 -fold increased risk of developing desmoid tumors compared to the general population, and $2 \%$ of all cases of desmoid tumors are associated with $\operatorname{FAP}^{(5,11,28)}$.

Desmoid tumors are the second most common cause of death in FAP patients after colorectal carcinoma. In view of this fact, surveillance to detect extracolonic manifestations assumes great importance in the follow-up of patients who have undergone prophylactic colectomy for $\operatorname{FAP}^{(13,14,15,32)}$.

Treating desmoids surgically has been associated with high rates of tumor recurrence. Several medical approaches have been used, but no evidence-based management is currently available for the treatment of this neoplasm. The use of chemotherapy, antiestrogen therapy, nonsteroidal anti-inflammatory drugs and radiotherapy with or without surgical resection have all been reported, resulting in varying levels of success $^{(9,}$ $10,31,35$. The aim of the present study was to review the occurrence of desmoid tumors in FAP cases following prophylactic colectomy and to present patient outcome.

\footnotetext{
The authors have no financial or non-financial competing interests to disclose.

Coloproctology Unit, Surgery Department and Pathology Department, University of Campinas (UNICAMP), Medical School, Campinas, SP, Brazil.

${ }^{1}$ Serviço de Coloproctologia, UNICAMP; ${ }^{2}$ Departamento de Anatomia Patológica, UNICAMP, Campinas, SP, Brazil.

Correspondence: Dr. Raquel Franco Leal - Rua Patativa, 170 - apt. 24C - Bonfim - 13034-810 - Campinas, SP, Brazil. E-mail: raquelleal@mpc.com.br
} 


\section{METHODS}

Between the years 1984 and 2008, 68 patients were submitted to colectomy for FAP at the School of Medical Sciences, Teaching Hospital of the University of Campinas (UNICAMP), SP, Brazil. Fifty-six (82.4\%) of these patients were submitted to proctocolectomy with ileal pouch-anal anastomosis (IPAA), $10(14.7 \%)$ to colectomy with ileorectal anastomosis and $2(2.9 \%)$ to proctocolectomy with permanent ileostomy. Desmoid tumors were found in $9(13.2 \%)$ of these patients, who were then studied retrospectively using data from their medical records. Data were obtained on the procedure used in colon surgery, on the postoperative follow-up presentation of the desmoid tumor, treatment, and patient outcome.

The study was carried out at the Coloproctology Unit, UNICAMP, and additional data were obtained from the files of the Department of Pathology, UNICAMP.

\section{RESULTS}

Six $(66.7 \%)$ of the nine patients who had desmoid tumors were female. The diagnosis of desmoid tumor was made based on clinical symptoms, the presence of an abdominal tumor and the results of abdominal ultrasonography or computed tomography during post-operative follow-up. In one of the patients, diagnosis was made during laparotomy, which had been required because of a small bowel obstruction. Seven patients $(77.8 \%)$ were submitted to laparotomy for tumor resection, their median age at the time of the surgery being 33.9 years (range 22-51 years). Another two patients of 35 and 38 years of age, respectively, were not submitted to surgery for the removal of their abdominal desmoids due to their clinical condition and the impossibility of resection, as revealed on computed tomography images. One of these two patients was treated with tamoxifen and a nonsteroidal anti-inflammatory drug (NSAID), resulting in a decrease in the size of the tumor and control of the disease. In the other case, the desmoid tumor continued to grow despite the use of tamoxifen; however, no further information was available because the patient was lost-to-follow-up. It is interesting to note that in this series none of the patients were related and there was no association with pregnancy.

In three of the nine patients $(33.3 \%)$, the desmoid tumor was found in the abdominal wall (Figure 1), while the tumor was intra-abdominal in the remaining six (66.7\%) (Figure 2). In one of the seven patients who underwent laparotomy, complete removal of the tumor proved impossible, however, diagnosis was confirmed in a biopsy specimen. This patient is currently using tamoxifen and NSAIDs; however, response is poor. In four patients who were submitted to resection, no evidence of a recurrent desmoid tumor was found at a median time of 43.3 months following surgery (range 15-60 months). With respect to the other two patients, one had a recurrence following surgery and in this case resection was impossible, while the other, whose tumor was in the abdominal wall, developed a recurrence in the form of a pelvic desmoid tumor,

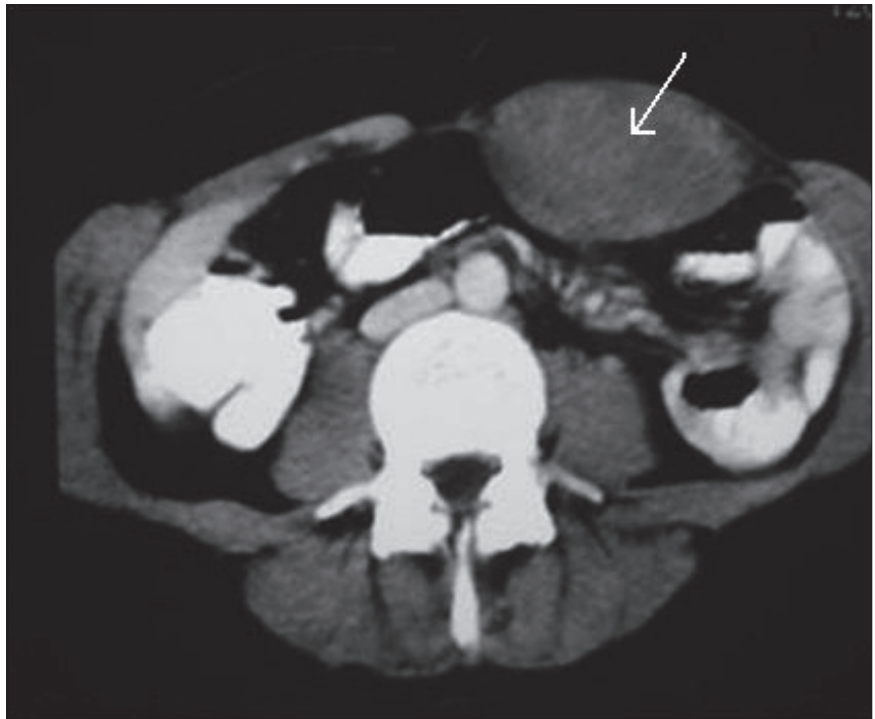

FIGURE 1. A desmoid tumor in the abdominal wall

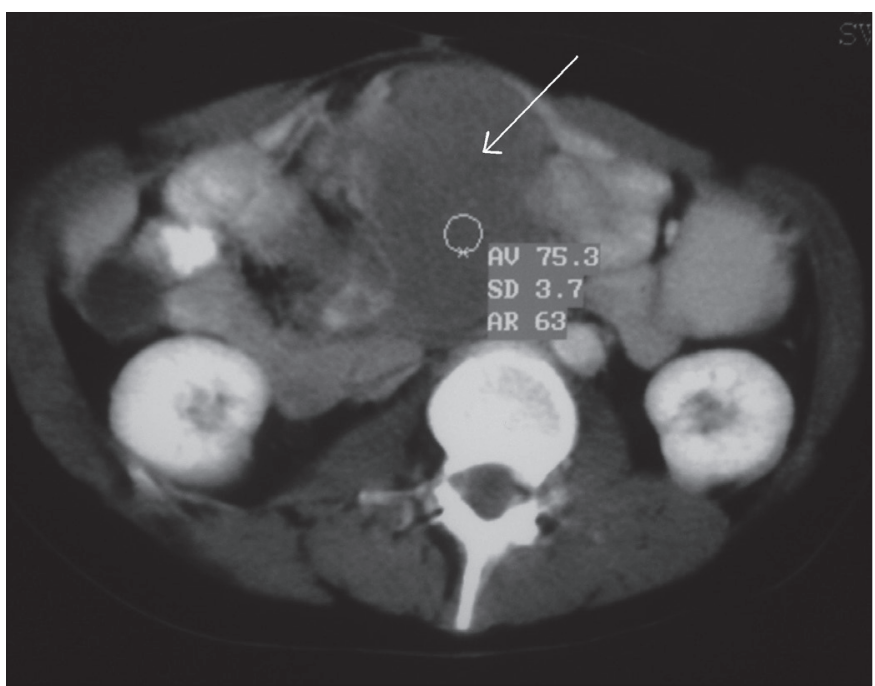

FIGURE 2. Intra-abdominal desmoid tumor

which was treated with Sulindac ${ }^{\circledR}$, resulting in a reduction in tumor size. This patient has been followed-up for over 15 years. Ureteric obstruction did not occur in any of these cases.

The median time elapsed between IPAA and diagnosis of the desmoid tumor was 37.5 months (range 14-60 months), whereas the median time between colectomy and ileorectal anastomosis to diagnosis of the desmoid tumor was 63.7 months (range 25-116 months). One patient, who was submitted to proctocolectomy including total removal of the anal canal because of rectal cancer associated with FAP, developed a desmoid tumor 12 months after surgery. In another patient, a desmoid tumor had been found in the abdominal wall 12 years prior to colectomy for FAP. The characteristics of the abdominal desmoid tumors detected in these nine patients are summarized in Table 1. 
TABLE 1. Characteristics of the desmoid tumor cases detected in the study population

\begin{tabular}{|c|c|c|c|c|c|c|c|}
\hline Patient & $\begin{array}{l}\text { Age } \\
(\mathrm{yr})\end{array}$ & Gender & $\begin{array}{l}\text { Time up to desmoid appearance } \\
\text { following colon surgery (months) }\end{array}$ & Type & Surgery & $\begin{array}{l}\text { Adjuvant } \\
\text { treatment }\end{array}$ & Follow-up \\
\hline 1 & 28 & F & 14 & $*$ & Resection & None & No recurrence 2 years later \\
\hline 2 & 30 & $\mathrm{~F}$ & 28 & $* *$ & $\begin{array}{l}\text { Resection with enteric } \\
\text { anastomosis }\end{array}$ & Tamoxifen; Celecoxib ${ }^{\circledR}$ & No recurrence 5 years later \\
\hline 3 & 22 & $\mathrm{~F}$ & 25 & $* *$ & $\begin{array}{l}\text { Resection with enteric } \\
\text { anastomosis }\end{array}$ & Tamoxifen; Celecoxib ${ }^{\circledR}$ & $\begin{array}{l}\text { Recurrence, } \\
\text { not resected; slowly growing } \\
\text { tumor; } 3 \text { years of follow-up }\end{array}$ \\
\hline 4 & 43 & M & 60 & $* *$ & Resection & None & No recurrence 5 years later \\
\hline 5 & 27 & $\mathrm{~F}$ & 146 & $*$ & Resection & Sulindac ${ }^{\circledast}$ & $\begin{array}{l}\text { Pelvic recurrence; not resected. } \\
\text { No progression; } 20 \text { years of } \\
\text { follow-up }\end{array}$ \\
\hline 6 & 26 & $\mathrm{~F}$ & 50 months before & $* *$ & No resection & Tamoxifen & Progression; lost to follow-up \\
\hline 7 & 34 & M & 48 months before & $* *$ & No resection & Tamoxifen; Celecoxib ${ }^{\circledR}$ & No progression 4 years later \\
\hline 8 & 36 & $\mathrm{~F}$ & 116 & $*$ & Resection & Sulindac ${ }^{\circledR}$ & No recurrence 4 years later \\
\hline 9 & 57 & M & 12 & $* *$ & $\begin{array}{l}\text { No resection (only } \\
\text { biopsy) }\end{array}$ & Tamoxifen; Celecoxib ${ }^{\circledR}$ & $\begin{array}{l}\text { Slowly growing desmoid; } 1 \text { year } \\
\text { of follow-up }\end{array}$ \\
\hline
\end{tabular}

Desmoid tumor in the abdominal wal

** Desmoid tumor in the mesentery

Finally, of these nine patients, either the disease was controlled or no evidence of a recurrence of the desmoid tumor was detected in six cases $(66.7 \%)$ after a mean followup of 63.1 months (range 12-240 months). Seven patients $(77.8 \%)$ remain in treatment, consisting principally of the use of tamoxifen and/or NSAIDs.

Microscopically, the lesions consisted of bland, spindleshaped cells evenly deposited in a collagenous stroma with myxoid change (Figure 3).

\section{DISCUSSION}

Desmoid tumors represent one of the most significant causes of the morbidity and mortality that affects FAP patients following colectomy. For this reason, an analysis was performed of cases of desmoid tumors associated with FAP, including their treatment and outcome, in order to acquire further knowledge on these tumors and study the clinical management of this disease. The incidence of desmoid

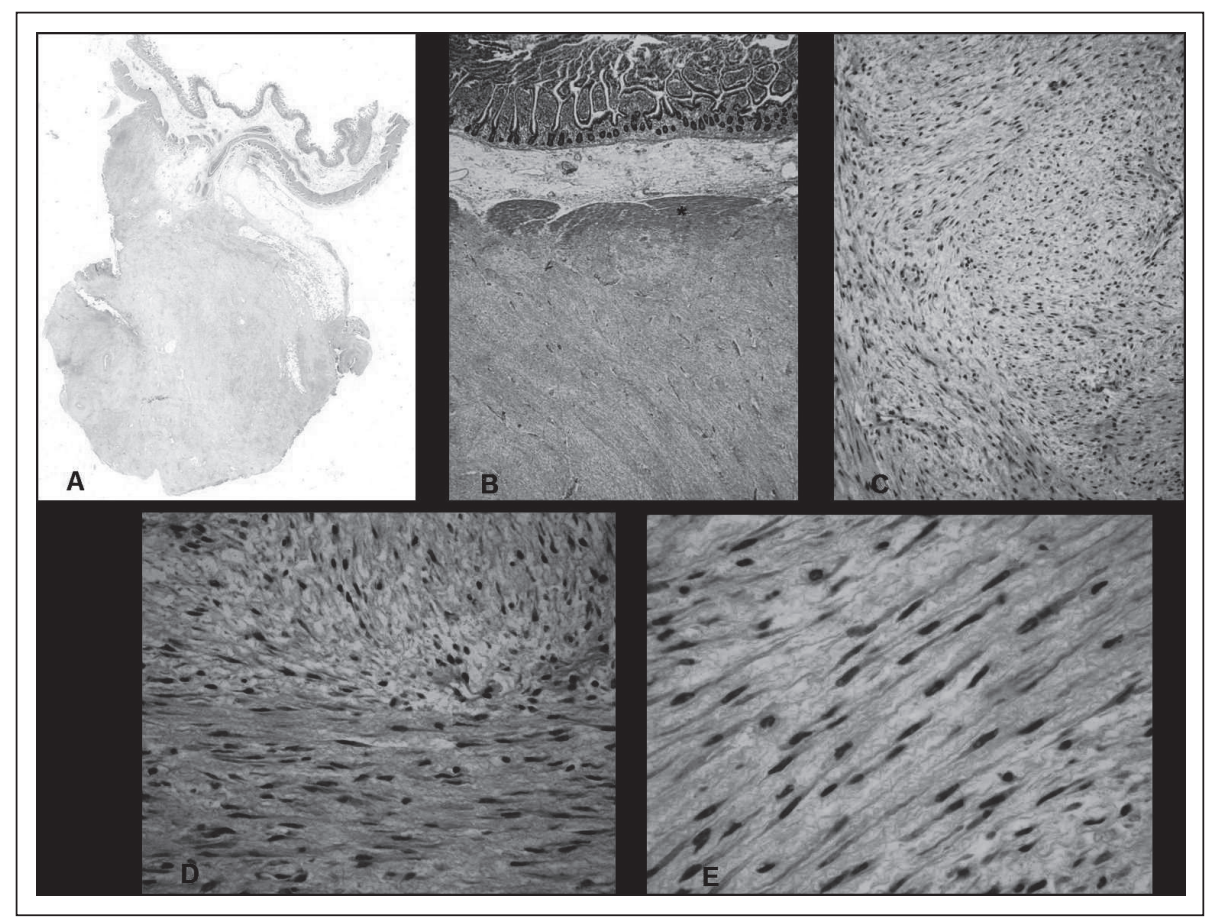

FIGURE 3. A) Panoramic view of mesenteric fibromatosis, forming a mass involving the wall of the small bowel and mesenteric fat. B) Low-power view of mesenteric fibromatosis showing uniform fibrocollagenous growth infiltrating the wall and attached to the muscular coat of the small bowel (*). C), D), E) Orderly arrangement and interlacing bundles of uniform spindled fibroblast proliferation, separated by varying amounts of collagen and mucoid material in mesenteric fibromatosis 
tumors is relatively high in FAP. The present findings show that $13.2 \%$ of patients $(9 / 68)$ developed desmoid tumors in the abdominal wall or intra-abdominally, while $66.7 \%$ (6/9) showed no evidence of any recurrence or their disease remained under control.

Gurbuz et al. ${ }^{(8)}$ reported a rate of $10 \%$ of desmoid tumors in FAP patients, while Sagar et al. ${ }^{(28)}$ reported a rate of $5.6 \%$. Lefevre et al. ${ }^{(16)}$ reported a rate of $11.3 \%$ in their review of 442 patients with FAP, the only modifiable factor being the type of surgical procedure; however, this was not found to have any significant effect on the risk of developing a desmoid tumor and did not modify the management of FAP patients ${ }^{(16)}$.

Genetic data is helpful in defining patients with a higher risk for desmoids, who may benefit from specific prevention therapy. Bertario et al. ${ }^{(2)}$ found a rate of $11.9 \%$ of desmoid tumors in their FAP population and reported that APC mutations beyond codons 1444 and 1309 were indicative of a 12 -fold and 17-fold increased risk, respectively. However, Stuart et al. ${ }^{(30)}$ found no correlation between APC gene mutation and a predisposition to developing a desmoid tumor. More recently, Lips et al. ${ }^{(17)}$ associated mutations in both the APC and beta-catenin genes with the formation of desmoid tumors. Studies have reported biallelic mutations in the human MutY homolog (MYH) gene in $29 \%$ of patients with FAP; therefore mutation analysis of this gene should be considered ${ }^{(22)}$. Unfortunately, no genetic testing results were available for the present review. Family surveillance is very important and, although no cases of desmoid tumors in the same family were found in the present study, we have broadened surveillance criteria by including annual abdominal ultrasonography or abdominal computed tomography scan in their follow-up. The pathogenesis is not completely clear and desmoid tumors have become the greatest remaining challenge in the treatment of FAP after the management of duodenal adenomas and colorectal cancer.

High doses of tamoxifen, a selective estrogen receptor modulator, and NSAIDs such as Sulindac ${ }^{\circledR}$ or Celecoxib ${ }^{\circledR}$ are recommended as the primary treatment for patients with FAP-associated desmoid tumors ${ }^{(10,33)}$. However, primary surgery, whenever possible, has been indicated for small, well-defined tumors with clear margins on image findings. Drugs help prevent recurrences and control progression of the disease in these cases. These tumors often involve the small bowel mesentery, making complete removal difficult or impossible, and they may also involve the ureters or superior mesenteric veins, increasing morbidity and mortality. Small bowel obstruction is a common occurrence and was found in the present sample in those patients who had intra-abdominal tumors ${ }^{(24,29)}$. In this series, there were no cases of complications due to ureteric obstruction, although this has been reported in rare cases of abdominal desmoid tumors ${ }^{25,26)}$.
Resection in cases of recurrent disease is frequently a more aggressive procedure than that used for the initial desmoid and may involve removal of a varying length of the small bowel ${ }^{7}$, 19). In the current sample population, removal of the entire tumor proved impossible in two patients who were submitted to surgery for recurrence of an abdominal desmoid. In these cases, drugs (tamoxifen, Sulindac ${ }^{\mathbb{B}}$ ) were used to control the disease. Although resection was not possible, the patients are well and are being managed clinically. Chemotherapy should be considered for the treatment of aggressive desmoids in which there is a risk of morbidity or mortality if surgery were performed, and also for the management of desmoid tumors that fail to respond to tamoxifen or NSAIDs ${ }^{(1,18,}$ ${ }^{25)}$. None of the patients in the present sample has required chemotherapy up to the present moment.

Although none of the female patients in this series developed desmoid tumors during pregnancy, this condition has been reported to improve the course of abdominal desmoid tumors in FAP due to the fact that they may be estrogen-dependent ${ }^{(4,20)}$.

In relation to the type of colon surgery and the appearance of a desmoid tumor, Nieuwenhuis et al. ${ }^{(23)}$ reported on a cohort in which they found a rate of $9 \%$ of desmoid tumors and Von Roon et al. ${ }^{(34)}$ also focused on this point of discussion. These authors concluded that there are no significant differences in the diagnosis rates of desmoid tumors when IPAA and ileorectal anastomosis are compared, however, they recommended IPAA for patients with a positive family history of desmoids, since in their experience, it was impossible to convert ileorectal anastomosis to IPAA in some patients with FAP, as proved necessary when the presence of desmoids was detected ${ }^{(6,34)}$.

\section{CONCLUSIONS}

FAP patients must be followed up closely and abdominal examination should be performed to detect any signs or symptoms of an abdominal tumor. In most patients, surgery is used to manage any obstructive complications and for the treatment of small, simple desmoid tumors or those shown as having clear margins on computed tomography scans. Alternative therapies with antiestrogens and anti-inflammatory drugs and chemotherapy must be considered in the case of aggressive desmoids or in patients in whom the preoperative surgical risk is considerable.

Despite current knowledge, management of desmoid tumors remains controversial with regard to decisions concerning surgery and adjuvant therapy. Consequently, more research is required to develop alternative treatment strategies to decrease the morbidity and mortality associated with desmoids in FAP patients. Further studies will be necessary to improve clinical management in these cases. 
Leal RF, Silva PVVT, Ayrizono MLS, Fagundes JJ, Amstalden EMI, Coy CSR. Tumor desmóide em pacientes com polipose adenomatosa familiar. Arq Gastroenterol. 2010;47(4):373-8.

RESUMO - Contexto - Os tumores desmóides representam uma das manifestações extraintestinais mais importantes na síndrome da polipose adenomatosa familiar. O aparecimento desta neoplasia está relacionada ao aumento da morbimortalidade nos doentes com polipose adenomatosa familiar. Objetivos - Avaliar a ocorrência dos tumores desmóides nos casos de polipose adenomatosa familiar submetidos a colectomia profilática e avaliar o seguimento em ambulatório. Métodos - Entre 1984 e 2008, 68 pacientes foram submetidos a colectomia por polipose adenomatosa familiar no Hospital das Clínicas da Faculdade de Ciências Médicas da Universidade de Campinas, SP. Os tumores desmóides ocorreram em nove pacientes (13.2\%), que foram estudados retrospectivamente, por meio da análise de prontuários, buscando dados clínicos e cirúrgicos. Resultados - Dos nove pacientes, sete (77,8\%) foram submetidos a laparotomia para ressecção do tumor. A média de idade no momento da cirurgia foi de 33,9 anos (variando 22-51 anos). Os tumores desmóides da parede abdominal ocorreram em 3/9 casos (33.3\%) e os intra-abdominais em seis casos (66,7\%). O tempo médio entre a cirurgia do reservatório ileal e o diagnóstico do tumor desmóide foi de 37,5 meses (variando 14-60 meses), enquanto o tempo médio entre a cirurgia de colectomia com anastomose íleorretal e o diagnóstico foi de 63,7 meses (variando 25-116 meses). Em 6/9 (66,7\%) pacientes com tumor desmóide, a doença estava controlada ou não havia evidência de recidiva do tumor em 63,1 meses (variando de 12 a 240 meses) de tempo médio de seguimento. Conclusão - Os tumores desmóides ocorreram em 13,2\% dos casos de polipose adenomatosa familiar após a cirurgia do cólon; desta maneira, os pacientes com polipose adenomatosa familiar devem manter seguimento em ambulatório e o rastreamento deve incluir o exame abdominal minucioso a fim de identificar sinais e sintomas que possam conduzir ao diagnóstico de tumor desmóide. As opções de tratamento incluem cirurgia e manejo clínico com antiestrogênios, anti-inflamatórios ou quimioterapia.

DESCRITORES - Fibromatose abdominal. Polipose adenomatosa do cólon. Anastomose cirúrgica. Bolsas do cólon.

\section{REFERENCES}

1. Azzarelli A, Gronchi A, Bertulli R, Tesoro JD, Baratti D, Pennacchioli E, Dileo P, Rasponi A, Ferrari A, Pilotti S, Casali PG. Low-dose chemotherapy with methotrexate and vinblastine for patients with advanced aggressive fibromatosis. Cancer. 2001;92:1259-64.

2. Bertario L, Russo A, Sala P, Eboli M, Giarola M, D'Amico F, Gismondi V, Varesco L, Pierotti MA, Radice P; Hereditary Colorectal Tumours Registry. Genotype and phenotype factors as determinants of desmoid tumors in patients with familial adenomatous polyposis. Int J Cancer. 2001;95:102-7.

3. Campos FG, Habr-Gama A, Kiss DR, Atuí FC, Katayama F, Gama-Rodrigues J. Extracolonic manifestations of familial adenomatous polyposis: incidence and impact on the disease outcome. Arq Gastroenterol. 2003;40:92-8.

4. Church JM, McGannon E. Prior pregnancy ameliorates the course of intraabdominal desmoid tumors in patients with familial adenomatous polyposis. Dis Colon Rectum. 2000;43:445-50.

5. Farmer KC, Hawley PR, Phillips RK. Desmoid disease. In: Phillips RK, Spigelman AD, Thomson JP, editors. Familial adenomatous polyposis and other polyposis syndromes. London: Edward Arnold; 1994. p.128-42.

6. Groen EJ, Roos A, Muntinghe FL, Enting RH, de Vries J, Kleibeuker JH, Witjes MJ, Links TP, van Beek AP. Extra-intestinal manifestations of familial adenomatous polyposis. Ann Surg Oncol. 2008;15:2439-50.

7. Guillem JG, Wood WC, Moley JF, Berchuck A, Karlan BY, Mutch DG, Gagel RF, Weitzel J, Morrow M, Weber BL, Giardiello F, Rodrigues-Bigas MA, Church J, Gruber S, Offit K. ASCO/SSO review of current role of risk-reducing surgery in common hereditary cancer syndromes. Ann Surg. 2006;13:1296-321.

8. Gurbuz AK, Giardiello FM, Petersen GM, Krush AJ, Offerhaus GJ, Booker SV, Kerr MC, Hamilton SR. Desmoid tumors in familial adenomatous polyposis. Gut. 1994:35:377-81.

9. Hamilton L, Blackstein M, Berk T, McLeod RS, Gallinger S, Madlensky L, Cohen Z. Chemotherapy for desmoid tumours in association with familial adenomatous polyposis - a report of three cases. Can J Surg. 1996;39:247-52.

10. Hansmann A, Adolph C, Vogel T, Unger A, Moeslein G. High-dose tamoxifen and sulindac as first-line treatment for desmoid tumors. Cancer. 2004;100:612-20

11. Heiskanen I, Järvinen HJ. Occurrence of desmoid tumors in familial adenomatous polyposis and results of treatment. Int J Colorectal Dis. 1996;11:157-62.

12. Jones IT, Jagelman DG, Fazio VW, Lavery IC, Weakley FL, McGannon E. Desmoid tumors in familial polyposis coli. Ann Surg. 1986;204:94-7.

13. Klemmer S, Pascoe L, DeCosse J. Occurrence of desmoids in patients with familial adenomatous polyposis of the colon. Am J Med Genet. 1987;28:385-92.

14. Leal RF, Ayrizono ML, Coy CS, Callejas-Neto F, Fagundes JJ, Góes JR. Gastroduodenal polyposis in patients with familiar adenomatous polyposis after rectocolectomy. Arq Gastroenterol. 2007;44:133-6.
15. Leal RF, Ayrizono ML, Coy CS, Fagundes JJ, Góes JR. Short-term and longterm postoperative complications after ileal pouch-anal anastomosis in familial adenomatous polyposis. Arq Gastroenterol. 2008;45:106-10.

16. Lefevre JH, Parc Y, Kernéis S, Goasguen N, Benis M, Parc R, Tiret E. Risk factors for development of desmoid tumors in familial adenomatous polyposis. Br J Surg. 2008;95:1136-9.

17. Lips DJ, Barker N, Clevers H, Hennipman A. The role of APC and beta-catenin in the aetiology of aggressive fibromatosis (desmoid tumors). Eur J Surg Oncol. 2009:35:3-10.

18. Lynch HT, Fitzgibbons R Jr, Chong S, Cavalieri J, Lynch J, Wallace F, Patel $\mathrm{S}$. Use of doxorubicin and dacarbazine for the management of unresectable intra-abdominal desmoid tumors in Gardner's syndrome. Dis Colon Rectum. 1994;37:260-7.

19. Melis M, Zager JS, Sondak VK. Multimodality management of desmoid tumors: how important is a negative surgical margin? J Surg Oncol. 2008;98:594-602.

20. Mulik V, Griffiths AN, Beattie RB. Desmoid tumors with familial adenomatous polyposis in pregnancy. J Obstet Gynaecol. 2003;23:307-8.

21. Naylor EW, Gardner EJ, Richards RC. Desmoid tumors and mesenteric fibromatosis in Gardner's syndrome: report of kindred 109. Arch Surg. 1979;114:1181-5.

22. Nielsen M, Franken PF, Reinards TH, Weiss MM, Wagner A, van der Klift H, Kloosterman S, Houwing-Duistermaat JJ, Aalfs CM, Ausems MG, Brocker-Vriends AH, Gomez-Garcia EB, Hoogerbrugge N, Menko FH, Sijmons RH, Verhoef S Kuipers EJ, Morreau H, Breuning MH, Tops CM, Wijnen JT, Vasen HF, Fodde F, Hes FJ. Multiplicity in polyp count and extracolonic manifestation in 40 Dutch patients with MYH associated polyposis coli (MAP). J Med Genet. 2005;42:e54.

23. Nieuwenhuis MH, De Vos Tot Nederveen Cappel W, Botma A, Nagengast FM, Kleibeuker JH, Mathus-Vliegen EM, Dekker E, Dees J, Wijnen J, Vasen HF. Desmoid tumors in a Dutch cohort of patients with familial adenomatous polyposis. Clin Gastroenterol Hepatol. 2008;6:215-9.

24. Penna C, Tiret E, Parc R, Sfairi A, Kartheuser A, Hannoun L, Nordlinger B. Operation and abdominal desmoid tumors in familial adenomatous polyposis. Surg Gynecol Obstet. 1993;177:263-8.

25. Poritz LS, Blackstein M, Berk T, Gallinger S, McLeod RS, Cohen Z. Extended follow-up of patients treated with cytotoxic chemotherapy for intra-abdominal desmoid tumors. Dis Colon Rectum. 2001;44:1268-73.

26. Porru D, Stancati S, Giliberto GL, Gerardini M, Corinti M, Dionigi P, Rovereto B. Bilateral ureteral compression by multiple abdominal tumors in Gardner syndrome: case report and literature review. Urology. 2004;64:1031.

27. Reitamo JJ, Hävry P, Nykyri E, Saxén E. The desmoid tumor. I. Incidence, sex, age and anatomical distribution in the Finnish population. Am J Clin Pathol. 1982;77:665-73.

28. Sagar PM, Möslein G, Dozois RR. Management of desmoid tumors in patients after ileal pouch-anal anastomosis for familial adenomatous polyposis. Dis Colon Rectum. 1998;41:1350-6. 
29. Soravia C, Berk T, McLeod RS, Cohen Z. Desmoid disease in patients with familial adenomatous polyposis. Dis Colon Rectum. 2000;43:363-9.

30. Sturt NJ, Gallagher MC, Bassett P, Philp CR, Neale KF, Tomlinson IP, Silver AR, Phillips RK. Evidence for genetic predisposition to desmoid tumors in familial adenomatous polyposis independent of the germline APC mutation. Gut. 2004;53:1832-6.

31. Suit H, Spiro I. Radiation in the multidisciplinary management of desmoid tumors. Front Radiat Ther Oncol. 2001;35:107-19.

32. Tarta C, Teixeira CR, Burger MB, Rosito MA, Cardoso AA, Gus P, Damin D. Magnifying colonoscopy in the diagnosis of colorectal carcinoma invading the submucosa in familial adenomatous polyposis. Arq Gastroenterol. 2000;37:125-8.

33. Vasen HFA, Moslein G, Alonso A, Aretz S, Bernstein I, Bertario L, Blanco I, Bülow S, Burn J, Capella G, Colas C, Engel C, Frayling I, Frield W, Hes FJ, Hodgson
S, Järvinen H, Mecklin JP, Moller P, Myrhoi T, Nagengast FM, Parc Y, Phillips R, Clark SK, de Leon MP, Renkonen-Sinisalo L, Sampson JR, Stormorken A, Tejpar S, Thomas HJ, Wijnen J. Guidelines for the clinical management of familial adenomatous polyposis (FAP). Gut. 2008;57:704-13.

34. Von Roon AC, Tekkis PP, Lovegrove RE, Neale KF, Phillips RK, Clark SK. Comparison of outcomes of ileal pouch-anal anastomosis for familial adenomatous polyposis with and without previous ileorectal anastomosis. $\mathrm{Br}$ J Surg. 2008;95:494-8.

35. Wilcken N, Tattersall MH. Endocrine therapy for desmoid tumors. Cancer. 1991;68:1384-8.

Received 4/1/2010

Accepted 12/5/2010. 